\title{
Isolation and characterization of endophytic bacteria from ginger (Zingiber officinale Rosc.)
}

\author{
Dilfuza Jabborova**, Kannepalli Annapurna*, Mohina Fayzullaeva, Khurshid Sulaymonov, Dilbar Kadirova**, Zafarjon Jabbarov*** \\ and R. Z. Sayyed $* * * *$ \\ Laboratory of Medicinal Plants Genetics and Biotechnology, Institute of Genetics and Plant Experimental Biology, Uzbekistan Academy of Sciences, \\ Tashkent, Uzbekistan \\ *Division of Microbiology, ICAR-Indian Agricultural Research Institute, Pusa, New Delhi-110012, India \\ **Termez State University, Termez, Uzbekistan \\ ***Department of Soil Science and Agriculture, Faculty of Biology, National University of Uzbekistan, Tashkent, Uzbekistan \\ ****Department of Microbiology, PSGVP Mandal's, Arts, Science and Commerce College, Shahada-425409, Maharashtra, India
}

\section{Article Info}

Article history

Received 24 April 2020

Revised 15 June 2020

Accepted 17 June 2020

Published online 30 June 2020

Keywords

Ginger

Zingiber officinale Rosc.

Endophytic bacteria

Salt tolerance

IAA

Siderophore

Antifungal activity

\begin{abstract}
The present investigation was aimed to isolate and characterize endophytic bacteria from Ginger (Zingiber officinale Rosc.) plant with salt tolerance, antifungal activity, and plant growth-promoting traits. A total of 15 endophytic bacteria were isolated from ginger by standard microbiological culture methods. Nine endophytic bacterial isolates (GS1, GS2, GS3, GS4, GS6, GS7, GS8, GS9, and GS11) showed salt tolerance up to $10 \% \mathrm{NaCl}$ concentration. Six isolates showed salt tolerance up to $7-8 \% \mathrm{NaCl}$ concentrations. Studies on plant growth-promoting activity suggested that four endophytic bacterial isolates (GS2, GS5, GS8, and GS10) were positive for IAA production, siderophore production, and phosphate solubilization activity. All the endophytic bacterial isolates were screened for the production of enzymes. The result of the study revealed that maximum isolates have positive protease activity and this was followed by lipase and cellulase activities. While studying the antifungal activity of the bacterial isolates, it was determined that eight isolates showed antifungal activities against fungal strains $F$. globosum 905 and F. graminearium 611. Four endophytic bacterial isolates (GS4, GS6, GS8, and GS9) had antifungal activity against several fungal strains. The results indicated that endophytic bacteria were isolated from ginger with salt-tolerant and plant growth-promoting activities that were reported, that could be used as inoculants to establish a sustainable ginger production system.
\end{abstract}

\section{Introduction}

Ginger (Zingiber officinale Rosc.) is a spice and medicinal plant belonging to the Zingiberaceae family. Ginger has long been used in folk medicine in India and China. Especially, the wet and dry root of ginger is widely used in medicine and food industry in India. The wet root of $Z$. officinale is also used as a vegetable. It is used to make gingerbread, sweets, cakes, snacks, and soft drinks in many countries. It has been used in folk medicine for colds, sore throats, asthma, joint pain and stimulates appetite (Grzanna et al., 2015). Ginger is also rich in beneficial nutrients for example phosphorus, potassium, and calcium, which play important roles in human physiological processes. These substances play an important role in boosting human immunity and maintaining health (Zadeh and Kor, 2014). The dry rhizome of ginger is medicinal contains biologically active compounds. The rhizome contains carbohydrates,

Corresponding author: Dr. Dilfuza Jabborova Senior Scientific Researcher, Laboratory of Medicinal Plants Genetics and Biotechnology, Institute of Genetics and Plant Experimental Biology, Uzbekistan Academy of Sciences, Tashkent, Uzbekistan E-mail: dilfuzajabborova@yahoo.com

Tel.: +91-8595092177; +998-909107761

Copyright (C) 2020 Ukaaz Publications. All rights reserved.

Email: ukaaz@yahoo.com; Website: www.ukaazpublications.com fats, proteins, vitamins, minerals, amino acids, monoterpenoids (camphene, sineiol, borneol, citral curcumin, and linalool), gingerol, and sesquiterpenoids (Sharma, 2017). Microorganisms such as rhizobacteria and endophytic bacteria play an important role in increasing the growth, development, and productivity of plants (Egamberdieva et al., 2013; Egamberdieva et al., 2015, Egamberdieva et al., 2016, Egamberieva et al., 2017; Egamberdieva et al., 2018; Jabborova et al., 2018; Li et al., 2018; Sayyed et al., 2015).

Endophytic bacteria directly improve plant growth such as producing phytohormones IAA, gibberellins, cytokinins (Jabborova et al., 2015), solubilizing phosphate (Sharma et al., 2013), increase nutrients (Liu et al., 2016; Liu et al., 2017), increase stress tolerance in plants (Sagar et al., 2020), biological control of plant pathogens (Sayyed and Chincholkar, 2009; Sayyed et al., 2010; Shaikh et al., 2014; Reshma et al., 2018;) and nitrogen fixation (Li et al., 2018). Phosphate solubilizing and phytohormone producing bacteria improve plant growth and yield of crops (Sharma et al., 2013; Jabborova et al., 2015). The endophytic bacteria possess the capacity to solubilize and assimilate phosphates in plants (Kuklinsky-Sobral et al., 2004). The objective of this study was to isolate and characterize the endophytic bacteria from Ginger (Z. officinale) medicinal plant with salt tolerance, antifungal activity, and plant growth-promoting traits. 


\section{Materials and Methods}

\subsection{Determination of soil properties}

Soil samples were collected from Termez district, Surkhandaryo province (Figure 1). To determine the soil properties before experimenting, soil samples were collected from 0-10, 0-20, and 0$30 \mathrm{~cm}$ depth of soil. The total nitrogen content was determined by the Kjeldahl method. The phosphorus content by Machigin, the potassium content by Machigin-Protasov, and organic matter by Tyurin methods were analyzed (Table 1).

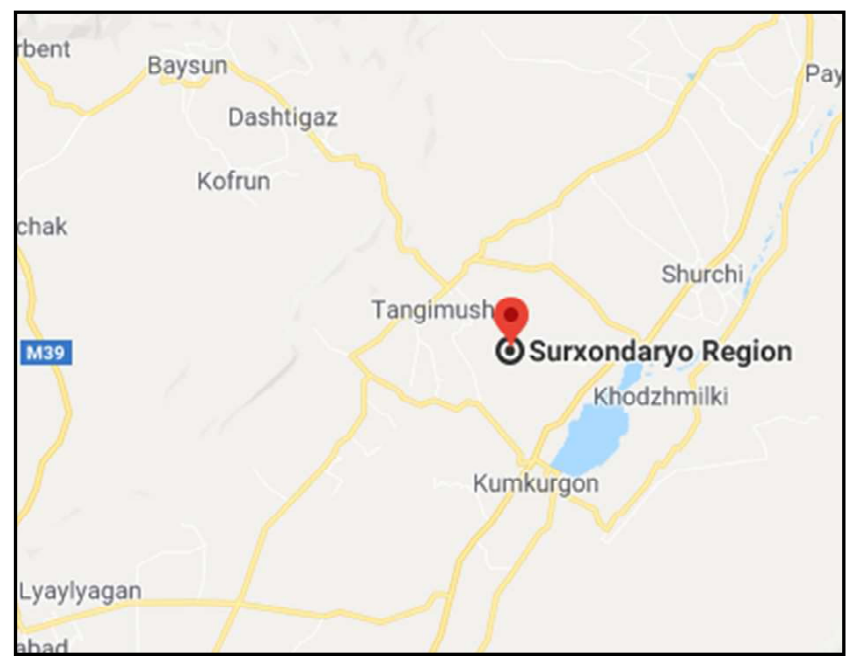

Figure 1: Map showing the location of the sampling sites. Surkhandaryo Region, Uzbekistan.

Table 1: Soil properties of field experiments

\begin{tabular}{|l|l|l|l|l|}
\hline $\begin{array}{l}\text { Soil } \\
\text { properties }\end{array}$ & $\begin{array}{l}\text { Total nitrogen } \\
(\mathbf{N}), \%\end{array}$ & $\begin{array}{l}\text { Phosphorus } \\
\left(\mathbf{P}_{\mathbf{2}} \mathbf{O}_{\mathbf{5}}\right), \%\end{array}$ & $\begin{array}{l}\text { Potassium } \\
\left(\mathbf{K}_{\mathbf{2}} \mathbf{O}\right), \boldsymbol{\%}\end{array}$ & $\begin{array}{l}\text { Organic } \\
\text { matter, \% }\end{array}$ \\
\hline $0-10 \mathrm{~cm}$ & 0.094 & 0.180 & 0.73 & 1.69 \\
$10-20 \mathrm{~cm}$ & 0.097 & 0.175 & 0.63 & 1.71 \\
$20-30 \mathrm{~cm}$ & 0.088 & 0.175 & 0.54 & 1.59 \\
\hline
\end{tabular}

\subsection{Isolation of endophytic bacteria}

For the isolation of endophytic bacteria, the ginger (Z. officinale) was collected from the Surkhandaryo Region, Uzbekistan (Figure 2). The bacterial endophytes were isolated from root, stem, and leaves of the healthy ginger plants. The plant samples were washed under running tap water for 10-15 min. to remove adhering soil particles, air-dried and roots, stem and leaves were separated. The separated plant root, stem, and leaves were weighed up to one gram on a weighing balance. The weighed samples were soaked in distilled water and drained. The samples were then surface-sterilized by dipping in $70 \%$ ethanol for $1 \mathrm{~min}$, stem and leave with $4 \%$ sodium hypochlorite for 5 minutes and roots with $2 \%$ sodium hypochlorite for $10 \mathrm{~min}$ and then treated with $70 \%$ ethanol for $30 \mathrm{sec}$, followed by rinsing five times in sterilized distilled water. The surfacesterilized samples were blot dried using sterile filter paper. The samples were crushed. The root, stem, and leaves samples serial dilutions were prepared, up to $10^{-5}$ dilutions. One hundred microliters from each dilution of the respective sample were then poured in their respective Petri-plates so labeled from $10^{-1}$ to $10^{-5}$ containing tryptone soy agar medium, KB agar medium, and nutrient agar medium separately. The plating was done in triplicate for each dilution. The plates were incubated at $28{ }^{\circ} \mathrm{C}$ for $2-4$ days for isolation of bacterial endophytes. The colonies of bacterial endophytes were picked and streaked on the 3 selective media for the selection of clone.

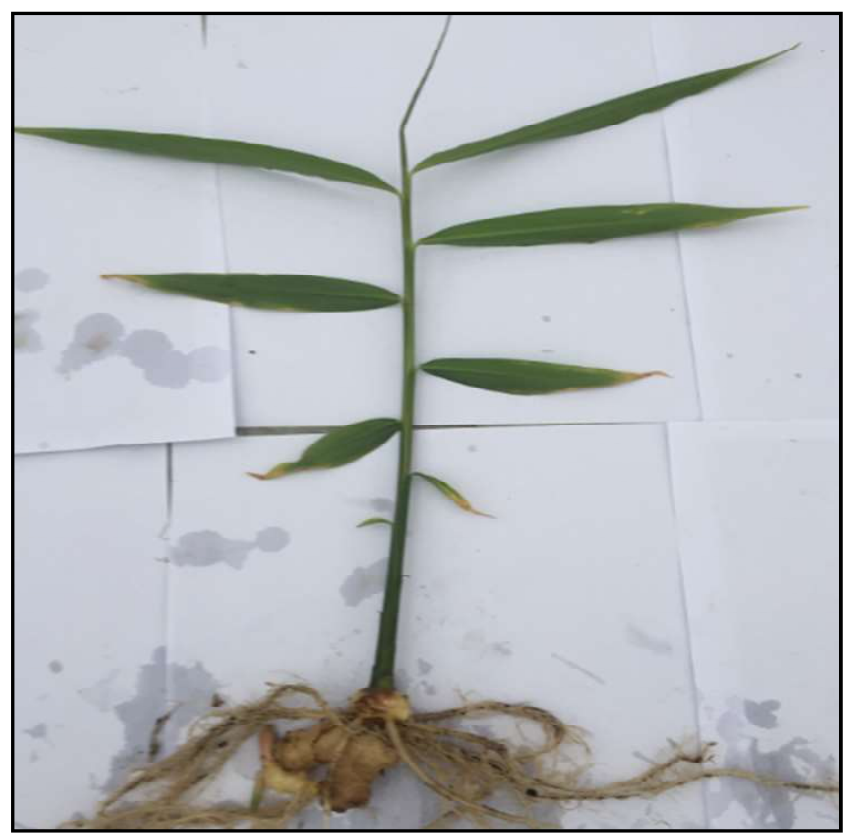

Figure 2: Ginger (Zingiber officinale) used in the present study for the isolation of endophytes.

\subsection{Salt tolerance}

$\mathrm{NaCl}$ was added into nutrient agar medium at various concentrations in the range of 1 to $10 \%$ and the test bacterial isolates were streaked.

\subsection{Phosphate solubilization}

Phosphate solubilization ability of bacterial endophytes was detected by spot inoculating pure bacterial endophytes on the Pikovskaya medium (Pikovskaya, 1948) and incubated at $28^{\circ} \mathrm{C}$ for three to seven days along with the control plates. The uninoculated plates served as control. All the inoculations were done in triplicate. After seven days of incubation at $28^{\circ} \mathrm{C}$, the formation of clearing zones were evaluated.

\subsection{Indole acetic acid (IAA) production}

Bacterial isolates were grown for $48 \mathrm{~h}$ on their respective media at $28^{\circ} \mathrm{C}$. Fully grown isolates were centrifuged at $3000 \mathrm{rpm}$ for 30 min. The supernatant $(2 \mathrm{ml})$ was mixed with two drops of orthophosphoric acid and $4 \mathrm{ml}$ of the Salkowski reagent $(50 \mathrm{ml}$, $35 \%$ of perchloric acid, $1 \mathrm{ml} 0.5 \mathrm{M} \mathrm{FeCl}_{3}$ solution). The development of pink color indicates IAA production (Brick et al., 1991).

\subsection{Siderophore production}

The bacterial isolates were spotted on the Chrome azurol S agar media as described (Patel et al., 2018). Isolates were incubated at $28{ }^{\circ} \mathrm{C}$ for $5-7$ days. The development of yellow-orange hallow zone around the bacterial spot has been considered as a positive indication for siderophore production. 


\subsection{Lipase production}

Production of lipase was carried out in a medium containing $\left(\mathrm{gL}^{-1}\right)$, (Ghodsalavi et al., 2013), peptone; 10, calcium chloride; 0.1, $\mathrm{NaCl}$; 5 , agar; 15 , distilled water $100 \mathrm{ml} ; 10 \mathrm{ml}$ sterile Tween 20 . All of the isolates were streaked on this medium and incubated at $27^{\circ} \mathrm{C}$ for $48 \mathrm{~h}$. Depositions around the bacterial colonies indicated the activity of the lipase enzyme.

\subsection{Production of protease}

The qualitative assay for protease production was performed on sterile skim milk agar containing $\left(\mathrm{gL}^{-1}\right)$ pancreatic digest of casein; 5.0, yeast extract; 2.5, glucose; 1.0, agar; 15.0, distilled water $1000 \mathrm{ml}$, skim milk (inducer), 7\%. Isolates were spot inoculated grown at $30{ }^{\circ} \mathrm{C}$ for $48 \mathrm{~h}$. After incubation plates were observed for the appearance of the zone of clearance around the colony indicating the enzymatic degradation of protease (Malleswari and Bagyanarayana, 2013).

\subsection{Production of cellulase}

Screening and production of the cellulose-degrading ability of bacterial isolates were performed by separately streaking each isolate on the cellulose congo red agar media containing $\left(\mathrm{gL}^{-1}\right)$ $\mathrm{KH}_{2} \mathrm{PO}_{4} ; 0.5, \mathrm{MgSO}_{4} ; 0.25$, cellulose; 2 , agar; 15 , congo red; 0.2 , gelatin; 2; distilled water $100 \mathrm{ml}$. pH was set to 6.8 with the help of $0.1 \mathrm{~N} \mathrm{HCl}$. Plates were incubated at $30{ }^{\circ} \mathrm{C}$ for $48 \mathrm{~h}$. After incubation clearance of halos around and beneath the colony was taken as an indication of the enzymatic degradation of cellulose (Gupta et al., 2012).

\subsection{Antifungal activity}

The bacterial isolates were tested for in vitro inhibitory effects against common phytopathogenic fungi namely: Fusarium sporotrichiodes 404, F. globosum 905, F. oxysporum 328, F. culmorum 903, F. graminearium $611, F$. solani 528 , and $F$. proliferatum 516. Fungal cultures were grown on the $\mathrm{ISP}_{2}$ agar plate at $28{ }^{\circ} \mathrm{C}$ for 5 days until the fungi had grown over control plates without bacteria. Antifungal activity was recorded as the width of the zone of growth inhibition between the fungus and the test bacterial isolates. All bacterial isolates were used in triplicate for the determination of antifungal activity.

\subsection{Statistical analysis}

Stat View software packages were used to perform Fisher's PLSD test following an ANOVA (SAS Institute Inc., Cary, NC, USA).

\section{Results}

\subsection{Salt tolerance test of bacterial isolates}

Fifteen bacterial isolates obtained from ginger showed varied tolerance to salt levels (Table 2). Nine endophytic bacterial isolates (GS1, GS2, GS3, GS4, GS6, GS7, GS8, GS9, and GS11) tolerated 10\% of NaCl. Four isolates (GS5, GS10, GS12, GS13, GS14, and GS15) tolerated up to $7 \%$ of $\mathrm{NaCl}$ and were inhibited at $9 \%$ and $10 \% \mathrm{NaCl}$ concentration.
Table 2: Salt tolerance of bacterial endophytes from Ginger (Z. officinale)

\begin{tabular}{|c|c|c|c|c|c|c|c|c|c|c|}
\hline $\begin{array}{l}\text { Bacterial } \\
\text { isolates }\end{array}$ & 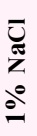 & 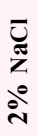 & 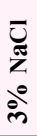 & $\begin{array}{l}\bar{J} \\
\text { ż } \\
\text { 巳े } \\
\dot{\nabla}\end{array}$ & $\begin{array}{l}\bar{J} \\
\text { z } \\
\text { in } \\
\text { in }\end{array}$ & $\begin{array}{l}\bar{J} \\
\tilde{z} \\
\text { ¿े }^{\circ}\end{array}$ & 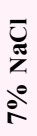 & $\begin{array}{l}\bar{J} \\
\underset{z}{Z} \\
\stackrel{\infty}{\infty}^{\circ}\end{array}$ & $\begin{array}{l}\bar{U} \\
\bar{z} \\
\stackrel{0}{ } \\
\stackrel{0}{ }\end{array}$ & 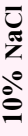 \\
\hline GS1 & + & + & + & + & + & + & + & + & + & + \\
\hline GS2 & + & + & + & + & + & + & + & + & + & + \\
\hline GS3 & + & + & + & + & + & + & + & + & + & + \\
\hline GS4 & + & + & + & + & + & + & + & + & + & + \\
\hline GS5 & + & + & + & + & + & + & + & - & - & - \\
\hline GS6 & + & + & + & + & + & + & + & + & + & + \\
\hline GS7 & + & + & + & + & + & + & + & + & + & + \\
\hline GS8 & + & + & + & + & + & + & + & + & + & + \\
\hline GS9 & + & + & + & + & + & + & + & + & + & + \\
\hline GS 10 & + & + & + & + & + & + & + & - & - & - \\
\hline GS11 & + & + & + & + & + & + & + & + & + & + \\
\hline GS12 & + & + & + & + & + & + & + & - & - & - \\
\hline GS13 & + & + & + & + & + & + & + & + & - & - \\
\hline GS14 & + & + & + & + & + & + & + & - & - & - \\
\hline GS 15 & + & + & + & + & + & + & + & + & - & - \\
\hline
\end{tabular}

\subsection{Plant growth-promoting traits}

A total of 15 bacterial isolates were isolated from the medicinal plant Z. officinale were screened for multiple plant growthpromoting traits such as phosphate solubilization, IAA production, siderophore production, and enzymes activities (Table 3). Most bacterial isolates exhibited one or more plant growth-promoting activities. Four bacterial isolates (GS2, GS5, GS8, and GS10) were able to solubilize phosphate and produce IAA, siderophore, lipase, protease, and cellulase.

Table 3: Overview of plant beneficial properties of the fifteen isolated bacterial isolates

\begin{tabular}{|c|c|c|c|c|c|c|}
\hline \multirow[b]{2}{*}{$\begin{array}{l}\text { Bacterial } \\
\text { isolates }\end{array}$} & \multicolumn{6}{|c|}{ Plant growth-promoting traits } \\
\hline & 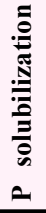 & 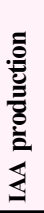 & 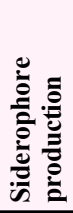 & 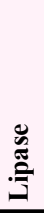 & 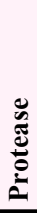 & 总 \\
\hline GS1 & + & - & - & + & + & - \\
\hline GS2 & + & + & + & + & + & + \\
\hline GS3 & + & + & + & + & + & - \\
\hline GS4 & + & + & - & - & - & + \\
\hline GS5 & + & + & + & + & + & + \\
\hline GS6 & + & + & - & - & - & - \\
\hline GS7 & + & - & - & + & - & - \\
\hline GS8 & + & + & + & + & + & + \\
\hline GS9 & - & + & - & + & + & + \\
\hline GS 10 & + & + & + & + & + & + \\
\hline GS11 & - & + & - & + & + & + \\
\hline GS 12 & - & - & + & - & - & + \\
\hline GS13 & + & + & + & - & + & + \\
\hline GS14 & + & - & + & + & + & - \\
\hline GS 15 & - & + & - & + & + & + \\
\hline
\end{tabular}

The results of the plant promoting growth test revealed that three isolates (GS9, GS11, and GS15) produce IAA, lipase, protease, and cellulase enzymes. Among all isolates, about $26 \%$ of them did not produce IAA (GS1, GS7, GS12, and GS14), lipase (GS4, GS6, GS12, 
and GS13), and protease (GS4, GS6, GS7, and GS12) and did not solubilize phosphate (GS9, GS11, GS12, and GS15). About $47 \%$ of the isolates (GS1, GS4, GS6, GS7, GS9, GS11, and GS15) did not produce siderophore. About $33 \%$ of bacterial isolates (GS1, GS3, GS6, GS7, and GS14) did not produce cellulase.

\subsection{Antifungal activity of endophytic bacterial isolates}

The endophytic bacterial isolates showed antifungal activity against selected fungal strains (Table 4). Thirteen isolates did not show antagonistic activity against fungal strain $F$. sporotrichiodes 404 . Eight bacterial isolates had antifungal activity against fungal $F$. globosum 905 (GS1, GS3, GS4, GS6, GS7, GS8, GS9, and GS15) and F. graminearium 611 (GS1, GS2, GS3, GS4, GS8, GS11, GS12, and GS13) strains. Three endophytic bacterial isolates exhibited antifungal property against fungal strains $F$. oxysporum 328 (GS4, GS11, and GS15) and F. culmorum 903 (GS2, GS6, and GS15). A total of 5 bacterial isolates exhibited antifungal property against fungal strains F. solani 528 (GS5, GS6, GS9, GS12, and GS13) and F. proliferatum 516 (GS5, GS6, GS7, GS8, and GS9).

Table 4: Antagonistic activity of bacterial endophytes from Ginger (Z. officinale) against some pathogenic fungi

\begin{tabular}{|c|c|c|c|c|c|c|c|}
\hline \multirow[b]{2}{*}{$\begin{array}{l}\text { Bacterial } \\
\text { isolates }\end{array}$} & \multicolumn{7}{|c|}{ Antifungal activity (fungal growth inhibition) } \\
\hline & 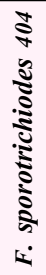 & 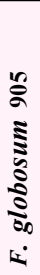 & 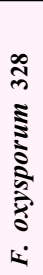 & 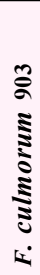 & 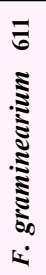 & 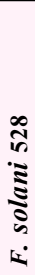 & 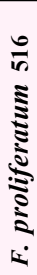 \\
\hline GS1 & - & + & - & - & + & - & - \\
\hline GS2 & - & - & - & + & + & - & - \\
\hline GS3 & - & + & - & - & + & - & - \\
\hline GS4 & - & + & + & - & + & - & - \\
\hline GS5 & - & - & - & & - & + & + \\
\hline GS6 & + & + & - & + & - & + & + \\
\hline GS7 & - & + & - & - & - & - & + \\
\hline GS8 & - & + & - & - & + & - & + \\
\hline GS9 & - & + & - & - & - & + & + \\
\hline GS10 & + & - & - & - & - & - & - \\
\hline GS11 & - & - & + & - & + & - & - \\
\hline GS12 & - & - & - & - & + & + & - \\
\hline GS13 & - & - & - & - & + & + & - \\
\hline GS14 & - & - & - & - & - & - & - \\
\hline GS15 & - & + & + & + & - & - & - \\
\hline
\end{tabular}

growth inhibition zone "+",

"-" - no inhibition

\section{Discussion}

The endophytic bacterial isolates were isolated from root, stem, and leaves of ginger. Endophytic bacteria previously reported in various medicinal plants such as Momordica charentia (Singh et al., 2013), Cassia tora (Kumar et al., 2015), Glycyrrhiza uralensis (Li et al., 2018), Talinum triangulare (Ali and Rante, 2018) and Thymes vulgaris (Mohamad et al., 2020).

Endophytic bacteria are particularly tolerant of environmental stresses such as high salinity, heat, and cold. Our results showed that the nine endophytic bacterial isolates (GS1, GS2, GS3, GS4,
GS6, GS7, GS8, GS9, and GS11) tolerated $10 \%$ of NaCl. Several other investigations have also reported that endophytic bacteria efficiently tolerated the high salt concentration (Kumar et al., 2015; Mohamad et al., 2020). Rashid et al. (2012) reported that Pseudomonas sp. tolerated up to $4 \% \mathrm{NaCl}$ and Bacillus sp. $2 \% \mathrm{NaCl}$. The endophytic bacterial strains of Curcuma longa L showed tolerance to the increasing salt concentration. B. thuringiensis (ECL2) and B. pumilus (ECL4) tolerated higher salt level $(8 \% \mathrm{NaCl})$ whereas $B$. cereus ECL1 and Bacillus sp. ECL3 tolerated 7\% of NaCl. Pseudomonas putida (ECL5) and Clavibacter michiganensis (ECL6) tolerated 6\% of $\mathrm{NaCl}$ concentration (Kumar et al., 2016).

Several endophytic bacteria interact positively, via., various mechanisms with their host plant. They produce plant growth, phosphate solubilization, IAA production, siderophore production, and activities of enzymes. In the present study, it was observed that several bacterial isolates isolated from medicinal plant $Z$. officinale were able to produce IAA, siderophore, enzymes, and solubilize phosphate (Table 2). Similar investigations indicated that endophytic bacteria exhibited plant beneficial traits (Singh et al., 2013; Ali and Rante, 2018; Mohamad et al., 2020). In this study production of IAA, siderophore, and solubilization phosphate was observed in four bacterial isolates namely GS2, GS5, GS8, and GS10, similar to the previous report by Mohamad et al. (2020). Mohamad et al. (2020) reported Bacillus sp. and Pseudomonas sp. with plant growth promotion and their activity was associated with the production of IAA and siderophore. Earlier research reported endophytic bacteria $B$. pumilusa and $P$. protegens produce siderophore (Etminani and Harighi, 2018).

Phosphorus is an important macronutrient necessary for plant growth and development. Phosphate solubilizing bacteria are capable of solubilizing the insoluble phosphate; enhance soil quality and plant growth and development of different plants (Sharma et al., 2013 and 2016; Jabborova et al., 2015). Kumar et al. (2016) reported solubilization in Bacillus cereus ECL1, Bacillus sp. ECL3, Bacillus pumilis ECL4, and Pseudomonas putida ECL5. In this research, all seven endophytic bacterial isolates (GS2, GS5, Gs8, GS9, GS10 GS11, and GS15) were able to produce different enzymes such as lipase, protease and cellulase enzymes (Table 2). These results are in general agreement with (Mohamad et al., 2020) who reported that endophytic bacteria associated with the medicinal plant, Thymes vulgaris capital were able to produce enzymes. Li et al., (2018) reported endophytic bacteria with the same capacity of producing plant growth-promoting traits.

Many endophytic bacteria exhibited antifungal properties that inhibit the growth of fungal pathogens. This study has demonstrated the antifungal activity of bacterial isolates (GS1, GS3, GS4, GS6, GS7, GS8, GS9, and GS15) against $F$. globosum 905 and $F$. graminearium 611 (GS1, GS2, GS3, GS4, GS8, GS11, GS12, and GS13) strains in Table 3. Our results showed that three endophytic bacterial isolates (GS4, GS11, and GS15) inhibited the growth of fungal strain $F$. oxysporum 328. Endophytic bacteria isolated from different medicinal plants have been reported to inhibit the growth of fungi (Kumar et al., 2016; Mohamad et al., 2020). Endophytic bacteria isolated from medicinal plant Glycyrrhiza uralensis have been reported to exhibit antifungal activity. Many of the previous studies have shown that endophytic bacteria control fungal pathogens, including Bacillus sp. ECL3 (Kumar et al., 2016), Bacillus 
atrophaeus (Mohamad et al., 2018) and Bacillus sp. and Pseudomonas sp. (Mohamad et al., 2020).

\section{Conclusion}

Nine endophytic bacterial isolates (GS1, GS2, GS3, GS4, GS6, GS7, GS8, GS9, and GS11) tolerated high salt ( $10 \%$ of $\mathrm{NaCl})$ concentration. Endophytic bacterial isolates have different abilities related to plant growth promotion such as solubilization of phosphate, IAA, siderophores, protease, lipase, and cellulase. Only four bacterial isolates (GS2, GS5, GS8, and GS10) were able to solubilize phosphate and produce IAA, siderophore, lipase, protease, and cellulase. All the bacterial isolates variously showed antifungal activity against selected fungal strains $F$. sporotrichiodes 404, F. globosum 905, $F$. graminearium $611, F$. oxysporum $328, F$. culmorum, F. solani, $F$. proliferatum 516 . Four endophytic bacterial isolates (GS4, GS6, GS8, and GS9) had antifungal activity against several fungal strains. This study provides future encouragement for the plant growthpromoting endophytic bacterial isolates (GS2, GS5, GS8, and GS10) for the improvement of eco-friendly biofertilizers to increase the ginger yield and enhance plant tolerance to salt stress.

\section{Acknowledgments}

This work has been financed by the Ministry of Innovational Development of the Republic of Uzbekistan and the Department of Biotechnology, Government of India (DBT), and TWAS.

\section{Conflict of interest}

The authors declare that there are no conflicts of interest in the course of conducting the research. All the authors had final decision regarding the manuscript and decision to submit the findings for publication.

\section{References}

Ali, A. and Rante, H. (2018). Screening of endophytic bacteria producing antifungal isolated from Indonesia medicinal plant, java ginseng (Talinum triangulare) (jacq.) willd. Intl. J. Pharm. and Pharmaceutl., 10(6): 152-158.

Bric, J.M.; Bostock, R.M. and Silverstone, S.E. (1991). Rapid in situ assay for indole acetic acid production by bacteria immobilized on the nitrocellulose membrane. Appl. Environ. Microbiol., 57(2):535-538.

Egamberdieva, D.; Jabborova, D. and Berg, G. (2016). Synergistic interactions between Bradyrhizobium japonicum and the endophyte Stenotrophomonas rhizophila and their effects on growth and nodulation of soybean under salt stress. Plant and Soil, 405(1):35-45.

Egamberdieva, D.; Jabborova, D.; and Hashem, A. (2015). Pseudomonas induces salinity tolerance in cotton (Gossypium hirsutum) and resistance to Fusarium root rot through the modulation of indole-3-acetic acid. Saudi J. Biol. Sci., 2:17-22.

Egamberdieva, D.; Jabborova, D. and Wirth, S. (2013). Alleviation of salt stress in legumes by co-inoculation with Pseudomonas and Rhizobium. In: Plant-Microbe Symbiosis-Fundamentals and Advances, Editor: Arora, N. K. Springer, India, pp:291-301.

Egamberdieva, D.; Jabborova, Dilfuza.; Stephan, Wirth.; Pravej, Alam.; Alyemeni, M.N. and Parvaiz, Ahmad. (2018). Interaction of magnesium with nitrogen and phosphorus modulates the symbiotic performance of soybean with Bradyrhizobium japonicum and its root architecture. Frontiers in Microbiol, 9:1-11.
Egamberdieva, D.; Wirth, S.; Jabborova, D.; Räsänen, L. A. and Liao, H. (2017). Coordination between Bradyrhizobium and Pseudomonas alleviates salt stress in soybean through altering root system architecture. J. Plant Interact., 12(1):100-107.

Etminani, F. and Harighi, B. (2018). Isolation and identification of endophytic bacteria with plant growth-promoting activity and biocontrol potential from wild pistachio trees. Plant Pathol. J., 34(3):208-217.

Ghodsalavi, B.; Ahmadzadeh, M.; Soleimani, M.; Madloo, P.B. and Taghizardfarid, R. (2013). Isolation and characterization of rhizobacteria and their effects on root extracts of Valeriana officinalis. Australian J. Crop Sci., 7(3):338-344.

Grzanna, R.; Lindmark, L. and Frondoza, C. (2005). Ginger-A herbal medicinal product with broad anti-inflammatory actions. J. Med. Food, 8(2):125-132.

Gupta, P.; Samant, K. and Sahu, A. (2012). Isolation of cellulase-degrading bacteria and determination of their cellulolytic potential. Intl. J. Microbiol., pp:1-5.

Jabborova, D. and Davranov, K. (2015). Effect of phosphorus and nitrogen concentrations on root colonization of Soybean (GLYCINE MAX L.) by Bradyrhizobium japonicum and Pseudomonas putida. International Journal of Advanced Biotechnology and Research, 6(3):418-424.

Jabborova, D.; Enakiev, Y.I.; Kakhramon, D. and Begmatov, S. (2018). Effect of coinoculation with Bradyrhizobium japonicum and Pseudomonas putida on root morph-architecture traits, nodulation, and growth of soybean in response to phosphorus supply under hydroponic conditions. Bulgarian J. Agric. Sci., 24(6):1004-1011.

Kuklinsky-Sobral, J.; Arau' jo, W.L.; Mendes, R.; Geraldi, I.O.; Pizzirani-Kleiner, A.A. and Azevedo, J.L. (2004). Isolation and characterization of soybean associated bacteria and their potential for plant growth promotion. Environ. Microbiology, 12:1244-1251.

Kumar, A.; Singh, R.; Yadav, A.; Giri, D.D.; Singh, P.K. and Pandey, K.D. (2016). Isolation and characterization of bacterial endophytes of Curcuma longa L. 3 Biotech., 6:60.

Kumar, V.; Kumar, A.; Pandey, K.D. and Roy, B.K. (2015). Isolation and characterization of bacterial endophytes from the roots of Cassia tora L. Ann. Microbiol., 65:1391-1399.

Li, L.; Mohamad, O. A.; Ma, J.; Friel, A. D.; Su, Y. and Wang, Y.; Musa Z.; Liu, Y.,Hedlund, B.P. and Li, W. (2018). Synergistic plant-microbe interactions between endophytic bacterial communities and the medicinal plant Glycyrrhiza uralensis F. Antonie van Leeuwenhoek, 111:1735-1748.

Liu, Y.; Guo, J.; Li, L.; Asem, M.D.; Zhang, Y.; Mohamad, O.A.; Salam, N. and Li, W. (2017). Endophytic bacteria associated with endangered plant Ferula sinkiangensis KM Shen in an arid land: Diversity and plant growth-promoting traits. J. Arid. Land, 9:432-445.

Liu, Y.H.; Guo, J.W.; Salam, N.; Li, L.; Zhang, Y.G.; Han, J.; Mohamad, O.S. and Li, W. (2016). Culturable endophytic bacteria associated with medicinal plant Ferula songorica: Molecular phylogeny, distribution and screening for industrially important traits. 3 . Biotech, 6:209.

Malleswari, D. and Bagyanarayan, G. (2013). In vitro screening of rhizobacteria isolated from the rhizosphere of medicinal and aromatic plants for multiple plant growth-promoting activities. J. Microbial. Biotechnol. Rev., 3(1):84-91. 
Mohamad, O.A.A.; Ma, J.; Liu, Y.; Zhang, D.; Hua, S.; Bhute, S.; Hedlund, B.; Li, W.; and Li, L. (2020). Beneficial endophytic bacterial populations associated with medicinal plant Thymus vulgaris alleviate salt stress and confer resistance to Fusarium oxysporum. Front. Plant Sci., pp:11-47.

Mohamad, O.A.A.; Li, L.; Ma, J.B.; Hatab, S.; Xu, L.; Guo, J.W.; Rasulov, B.A.; Liu, Y.; Hedlund, B.P. and Li, W. (2018). Evaluation of the antimicrobial activity of endophytic bacterial populations from Chinese traditional medicinal plant licorice and characterization of the bioactive secondary metabolites produced by Bacillus atrophaeus against Verticillium dahliae. Front Microbiol., 9:924.

Patel, P.R.; Shaikh, S.S. and Sayyed, R.Z. (2018). Modified chrome azurol S method for detection and estimation of siderophores having an affinity for metal ions other than iron. Env. Sust. pp(1):81-87.

Pikovskaya, R.I. (1948). Mobilization of phosphorous in the soil in connection with the vital activity of some microbial species. Microbiology, 17:362-370.

Rashid, S.; Charles, T.C. and Glick, B.R. (2012). Isolation and characterization of new plant growth-promoting bacterial endophyte. Appl. Soil Ecol., 61:217-224.

Reshma, P.; Naik, M.K; Aiyaz, M.; Niranjana, S.R.; Chennappa, G.; Shaikh, S.S. and Sayyed, R.Z. (2018). Induced systemic resistance by 2,4 diacetylphloroglucinol positive fluorescent Pseudomonas strains against rice sheath blight Indian J. Exp. Biol., 56(3):207-212.

Sagar, A.; Riyazuddin, R.; Shukla, P.K.; Ramteke, P.W. and Sayyed, R.Z. (2020). Heavy metal stress tolerance in Enterobacter sp. PR14 is mediated by plasmid, Indian J. Exp. Biol., 58(2):115-121.

Sayyed, R. Z and Chincholkar, S.B. (2009). Siderophore producing $A$. feacalis more biocontrol potential vis-a-vis chemical fungicide. Curr. Microbiol., 58(1):47-51.
Sayyed, R.Z.; Gangurde, N.S. and Chincholkar, S.B. (2010). Siderophore production by $A$. faecalis and its application for growth promotion in A. hypogaea, Indian J. Biotechnol., 9(3):302-307.

Sayyed, R.Z.; Patel, P.R. and Shaikh, S.S. (2015). Plant growth promotion and root colonization by EPS producing Enterobacter sp. RZS5 under heavy metal contaminated soil, Indian J. Exp. Biol., 53:116-123.

Seema, S.; Sayyed R.; Sonawane, M.; Trivedi, M. and Thivakaran, G. (2016). Neurospora sp. SR8, a novel phosphate solubiliser from rhizosphere soil of Sorghum in Kachchh, Gujarat, India Indian. Journal of Experimental Biology, 54:644-649.

Shaikh, S.S.; Patel, P.R.; Patel, S.S; Nikam, S.D; Rane, T.U; and Sayyed, R.Z. (2014). Production of biocontrol traits by banana field fluorescent Pseudomonads and comparison with chemical fungicide, Indian J. Exp. Biol., 52:917-920.

Sharma, S.B.; Sayyed, R.Z.; Trivedi, M.H. and Gobi, T. (2013). Phosphate solubilizing microbes: Sustainable approach for managing phosphorus deficiency in agricultural soils, Springer Plus, 2:587.

Sharma, Y. (2017). Ginger (Zingiber officinale): An elixir of life a review. The Pharma Innov. J., 6(10):22-27.

Singh, R.; Kumar, A.; Singh, M. and Pandey, K.D. (2013). Effect of salt stress on endophytic bacteria isolated from the root of Momordica charantia. In: Indian Society of Vegetable Science, National Symposium on Abiotic and Biotic Stress Management in Vegetable Crops.

Zadeh, J.B. and Kor, N.M. (2014). Physiological and pharmaceutical effects of ginger (Zingiber officinale Roscoe) as a valuable medicinal plant. Europian J. Exp. Biol., 4(1):87-90.

Citation: Dilfuza Jabborova, Kannepalli Annapurna, Mohina Fayzullaeva, Khurshid Sulaymonov, Dilbar Kadirova, Zafarjon Jabbarov and R. Z. Sayyed (2020). Isolation and characterization of endophytic bacteria from ginger (Zingiber officinale). Ann. Phytomed., 9(1):116-121. http://dx.doi.org/10.21276/ap.2020.9.1.14 